Vol. 14 (2005): 134-142.

\title{
Physical properties of synthetic bedding materials for free-stall dairy cow
}

\author{
Jukka Ruunaniemi, Mikko Hautala and Jukka Ahokas \\ Department of Agricultural Engineering and Household Technology, PO Box 66, FI-00014 University of Helsinki, \\ Finland,e-mail: jukka.ahokas@helsinki.fi
}

\begin{abstract}
Rest is a prerequisite for the well-being of cows and they spend 40-50\% of the time lying down. In this study the basic physical properties, the friction coefficient, heat flux as a function of time and softness of the bedding materials were measured. The heat flux to the bedding was shown to be large enough to affect the cow's heat balance. The friction coefficients of most of the tested materials were not within the recommended 0.3-0.5. However, the friction values are only indicative, as the material and the shape of the artificial hoof were not identical to natural hooves. There were also differences of almost an order of magnitude in the softness (Young's modulus) of the mats. Demands for softness vary according to the type of building and cow's physical condition, for instance a cow with an injured leg needs softer bedding. The properties of mats and beds varied considerably and the various properties did not correlate with each other. More information is needed concerning these values to animal welfare and health in order to be able to make recommendations of different physical material characteristics in different climate and housing conditions.
\end{abstract}

Key words: cows, synthetic bed, mats, bedding materials, physical properties

\section{Introduction}

The use of unheated cubicles for housing dairy cattle has increased in Finland since the 1990s. Straw is widely used as a bedding material, but weather conditions can greatly affect harvest yield and quality and the availability of dry straw. This, together with the need to reduce costs and mastitis (Hogan et al. 1989), has increased interest in re- ducing the use of organic bedding materials. Soft rubber mats and sand reduce the amount of organic bedding needed to maintain some flexibility (Irish and Martin 1983, Cermak 1988, Britten 1994). Bacteria content in sand has been reported to be lower than in organic bedding materials (Hogan et al. 1989), and cows lying on sand have fewer hock injuries than cows lying on sawdust or geotextile mattresses (Weary and Taszkun 2000). In unheated cubicle housing the thermal requirements of the 
Vol. 14 (2005): 134-142.

cows vary according to the season, so the effects of different types of bedding on cow welfare have to be investigated at different temperatures.

Lying time, that is the frequency and duration of lying bouts, has been used to measure cow comfort (e.g. Natzke et al. 1982, Müller et al. 1989, Munksgaard and Simonsen 1995, Herlin 1997, Haley et al. 2000). Preference tests have been widely used as a measure of animal welfare (Duncan 1992) and cow comfort on different cubicle floorings (Natzke et al. 1982, Herlin 1997, Müller and Botha 1997).

Cows spend $40-50 \%$ of the time lying down (Webster 1993). Dairy cows need to optimize their lying time, as disturbed rest may affect milk production by reducing the secretion of growth hormone (Munksgaard and Løvendahl 1993). Reduced lying time is also associated with hoof disease and lameness (Singh et al. 1993, Leonard et al. 1994, Faull et al. 1996, Sonck et al. 1999). In free stall or cubicle housing, poorly designed stalls lead to reduced stall occupancy (O'Connell et al. 1993), and the type of flooring in the stall may affect time spent lying down (Natzke et al. 1982, Herlin 1997, Sonck et al. 1999). Leg injuries are an increasing problem and are most probably connected to the change in lying material (see Wechsler et al. 2000).

The physical properties such as softness, friction and the warmth of lying surfaces are clearly an essential part of comfort (Nilsson 1988, 1992). Webster claims that softness is the most important property (Webster 1993). Manninen et al. (2002) observed that, in winter, the cows in cold free-stall housing preferred well bedded concrete stalls more than scarcely bedded, soft rubber mats. In summer, no difference was detected. Optimal lying area material thus also seems to depend on climatic and housing conditions.

The time dependent heat flow into the cubicle may affect on how long the cows lie. Nilsson has studied the subject most recently and thoroughly (Nilsson 1992). The article contains an extensive reference list. Nilsson measured the heat flow indirectly by measuring the heating power to keep an artificial cow at a constant temperature. The heat flow was first measured directly for pigs (Spillman and Hinkle 1971). Pigs usually lie for rather long periods and thus the heat flow is constant and can also be calculated by measuring temperatures at various depths. On the contrary cows typically lie for one hour at a time. Therefore, the time dependence of heat loss to the floor is relevant.

The aim of this study was to explore the basic physical properties of most common bedding materials in Finland. They were to be used in connection with studies of the preferences of dairy cows for different kinds of stall flooring materials (Manninen et al. 2002). In this study friction (static friction coefficient), softness (Young's modulus) and thermal properties (heat flux) of various commercial mats and beds were compared. The static friction was measured by moving an artificial hoof along a dry or wetted material. The softness was measured by pressing a ball or an artificial hoof against the material and measuring the deformation as a function of compressive force. The heat flux into the material from an artificial cow was measured with a heat flux sensor.

\section{Theory}

\section{Heat flux}

The cow mimics an infinite heat reservoir with constant temperature $\mathrm{T}_{1}$. If a semi-infinite obstacle with constant temperature $T_{2}<T_{1}$ is placed in contact with the reservoir, a time-dependent heat flux $\mathrm{q}\left(\mathrm{W} \mathrm{m}^{-2}\right)$ from the reservoir occurs (Andromeda and de Witt 1990)

$q=-\left.\lambda \frac{\partial T}{\partial x}\right|_{x=0}=\frac{\lambda}{\sqrt{\pi \alpha t}}\left(T_{2}-T_{1}\right)$,

where $\lambda$ and $\alpha$ are the heat conductivity and the heat diffusivity of the obstacle, respectively. The heat flux is thus proportional to $t^{-1 / 2}$, i.e. its limit is infinite when $t$ approaches zero. When heat flux is plotted as a function of time, on a log-log-scale we should get a straight line with slope $-1 / 2$. When 
the heat flux and the area of the cow against the floor are known, the heat power flow $\Phi=\mathrm{qA}$ may be calculated. This is necessary if the heat balance of the cow is to be calculated. If the total heat balance is zero, the cow feels comfortable, otherwise it feels either hot or cold. The thermal comfort of cow depends on the type of building and temperature. In warm conditions good insulation will induce sweating and in cold conditions large heat flow causes chilling. Bedding material has to be chosen according to the conditions in the building.

A cow is covered by fur, a thin insulating layer with thickness $\delta$ and heat conductivity $\lambda$ which can be described as a heat transfer coefficient $\mathrm{h}=$ $\lambda / \delta$. When this is included, we have a new equation for the heat flux (Incropeda and de Witt 1990)

$$
\begin{aligned}
& q=(T 2-T(0, t)) \\
& \frac{T(x, t)-T 1}{T 2-T 1}=\operatorname{erfc}\left(\frac{x}{2 \sqrt{\alpha t}}\right)-\left[\exp \left(\frac{h x}{\lambda}+\frac{h^{2} \alpha t}{\lambda^{2}}\right)\right] \\
& {\left[\operatorname{erfc}\left(\left(\frac{x}{2 \sqrt{\alpha t}}\right)+\frac{h \sqrt{\alpha t}}{\lambda}\right)\right]}
\end{aligned}
$$

\section{Softness}

If a material of area $\mathrm{A}$ and thickness $\mathrm{x}$ is pressed with a force $\mathrm{F}$, the thickness changes by $\Delta \mathrm{x}$. If $\Delta \mathrm{x}$ is linearly proportional to $\mathrm{F}$ (linearly elastic material), then Young's modulus $\mathrm{E}$ is defined by the Hooke's law

$$
\Delta \mathrm{x}=\frac{1}{E} x \frac{F}{A}
$$

The deformation increases as values of $\mathrm{E}$ decrease, soft materials have a low modulus value. There are no recommendations for the softness of a bed material. Demands for softness vary according to the building type. In free-stalls the animals only rest on the beds, but in tied-stalls they are on the beds all the time. The bedding needs to be soft enough to be comfortable but must allow move- ment. Hard bedding induces chafes and very soft bedding induces instability during movements (Nilsson 1988, Dumelow 1995, Tierney and Thomson 2001). The bedding acts also as cushioning material during kneeling and rising and for this purpose a soft material is good, but stability is reduced when standing on this material (Tierney and Thomson 2001).

\section{Friction}

If a standing load does not start to move on a cubicle material, when a horizontal force $\mathrm{F}$ is applied to it, the coefficient of static friction $\mu$ of the material-load pair at that instance is defined by the equation

$\mathrm{F}=\mu \mathrm{mg}$,

where $\mathrm{m}$ is the mass of the load and $\mathrm{g}$ is the acceleration due to gravity. The static friction coefficient comes from the smallest force that is capable to start the load moving. A horizontal force develops during walking or when a cow stands up or lies down. Static friction is always larger than dynamic friction when the hoof slips on the material.

The friction should not be too low or too high. A low coefficient of friction indicates a slippery bed and a high friction material causes chafing. A suitable value for friction is 0.3-0.5 (Wander 1970, Beer 1976, Bähr and Türpitz 1976, Nilsson 1978). When changing the bedding material it is probably important that the new material has at least the same coefficient of static friction as the one the cow is already used to, otherwise the new material is more slippery and the cow can hurt itself before it gets used to it.

\section{Material and methods}

Seven materials commercially available in Finland were chosen. Their properties are given in Table 1. 
Vol. 14 (2005): 134-142.

Table 1. Description of the bedding materials.

\begin{tabular}{llllllll}
\hline & UBO & RM 20N & KEN & KSL & Cow Comfort & Bovirex & KEW \\
\hline Thickness, mm & 17 & 20 & 20 & 30 & 22 & 38 & 30 \\
Material & Natural rubber & rubber & rubber & rubber & EVA $^{1}$ & EVA $^{1}$ & rubber/soft \\
Upper side & grooved & patterned & patterned & patterned & patterned & patterned & patterned \\
Underneath & grooved & toggles & toggles & toggles & smooth & studs & smooth \\
\hline
\end{tabular}

${ }^{1}$ ethylene vinyl acetate foam

Heat fluxes into the material from an artificial cow were measured with commercial TNO heat flux sensors (model PU11, Sensor Technology) at four separate points. The sensor diameter was 25 $\mathrm{mm}$. Temperatures of artificial cow and the material were measured with T-type thermocouples. The heat flux sensors and thermocouples were connected to a HP34970A-data logger. The data was recorded once a second during the first $6 \mathrm{~min}$ utes, then every 15 seconds during the first hour and after that once a minute. A plastic bag filled with water was used as a heat reservoir in order to make the contact with bedding as good as possible. The water in the bag was heated up to normal cow body temperature $\left(39^{\circ} \mathrm{C}\right)$ and it was kept uniform by circulating it with a pump in order to reduce the insulating effect of the stagnant layer. The initial temperature of the bedding was $10^{\circ} \mathrm{C}$. Several repetitive measurements were made for each material.

Friction was measured using an artificial hoof made of acryl. The hoof was $45 \mathrm{~mm} \times 50 \mathrm{~mm} \times$ $110 \mathrm{~mm}$ (contact area $45 \mathrm{~mm} \times 110 \mathrm{~mm}$ ) and it was pulled on the mat material using a railed carriage and an electrical motor. Pulling force was measured using a strain gage sensor and the data was collected with $20 \mathrm{~Hz}$ frequency with HBMMVD 2555 amplifier. The data was transferred via RS-port to a PC for calculations. The hoof could be loaded with weights of 30,90,120 and $170 \mathrm{~kg}$. The surfaces were either dry or wetted. To wet the surface 0.11 water was poured to the place hoof situated. For each surface five test runs were first made and after that the five final measurements. This ensured good repeatability of results.

The softness was measured by pressing both the hoof and an steel ball against the material using an INSTRON universal testing machine. The steel ball (diameter $10 \mathrm{~cm}$ ) mimicked the kneecap. The force was applied to the material with the testing machine and the measurement was stopped at 4.5 $\mathrm{kN}$ force. For each bedding material three test runs were made and the results are averaged from that data.

\section{Results}

Heat flux followed the theoretical equation of Eq. (1) (Fig. 1). In order to better show the dramatic change of heat flux as a function of time, linear scales have been used in Figure 1. At longer times the finite thickness causes deviations from the theoretical values. The differences between materials were significant, by as much as a factor of three. Both the values and differences are large enough to cause significant changes in the total heat balance. The optimal value of heat flux depends on the housing and climatic conditions, so it is not possible to give a recommendation for this value without heat balance calculations. Summer and winter can demand different kinds of bedding materials.

The friction measurements also followed the theoretical assumptions (Fig. 2). The initial peak in the force due to maximum static friction was followed by an almost constant force which was due to dynamic friction. The friction coefficients for dry materials for various loads were calculated from Eq. (4) (Fig. 3 and Table 2). Within experimental accuracy the static friction coefficient was independent of load. An interesting point in the friction data (Fig. 3 and Table 2) was that wetting the material with water did not noticeably change 
Ruunaniemi, J. et al. Physical properties of synthetic bedding materials for dairy cow

Fig. 1. Heat flux into the bedding materials as a function of time. The initial temperature of the bedding was $10^{\circ} \mathrm{C}$.

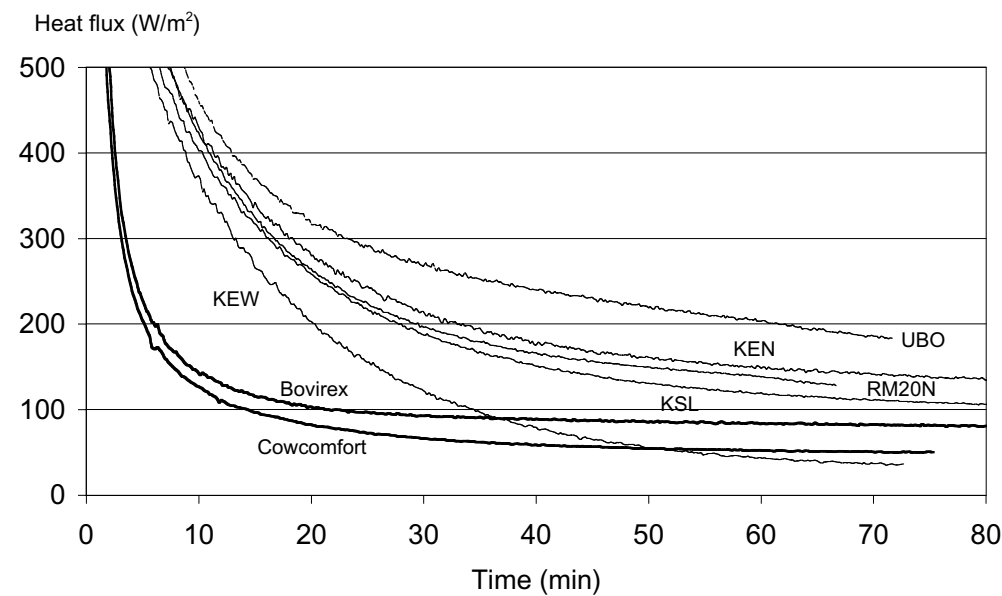

the friction coefficient. In Figure 3 some friction coefficients with load $170 \mathrm{~kg}$ are missing because the pulling force limits of the test system were reached. The $120 \mathrm{~kg}$ load was not used if the 170 $\mathrm{kg}$ load was measurable.

Results from the softness also showed significant differences between materials, both with the iron ball method (Fig. 4) and using the artificial hoof (Fig. 5). The pushing force in the iron ball test was not linearly dependent on deformation since the effective area over which the load is distributed increases when the ball penetrates into the material. The behaviour of the KEW-mat was very different from the others. This is due to the very soft material underneath the rubber mat. Finite element

Fig. 2. Example of friction measurements for the KEW mat with $90 \mathrm{~kg}$ load. The applied force is given as a function of time. The static friction coefficient is calculated from the maximum force.

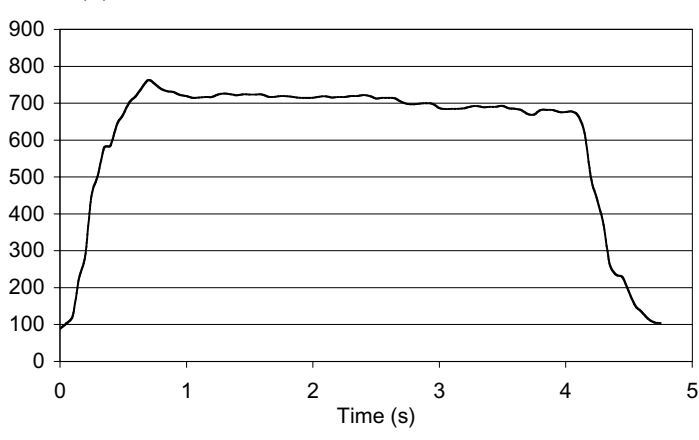

Fig. 3. Static friction coefficients for dry material loaded with 30 , 90,120 and $170 \mathrm{~kg}$. The error bars give the range of five repetitions.

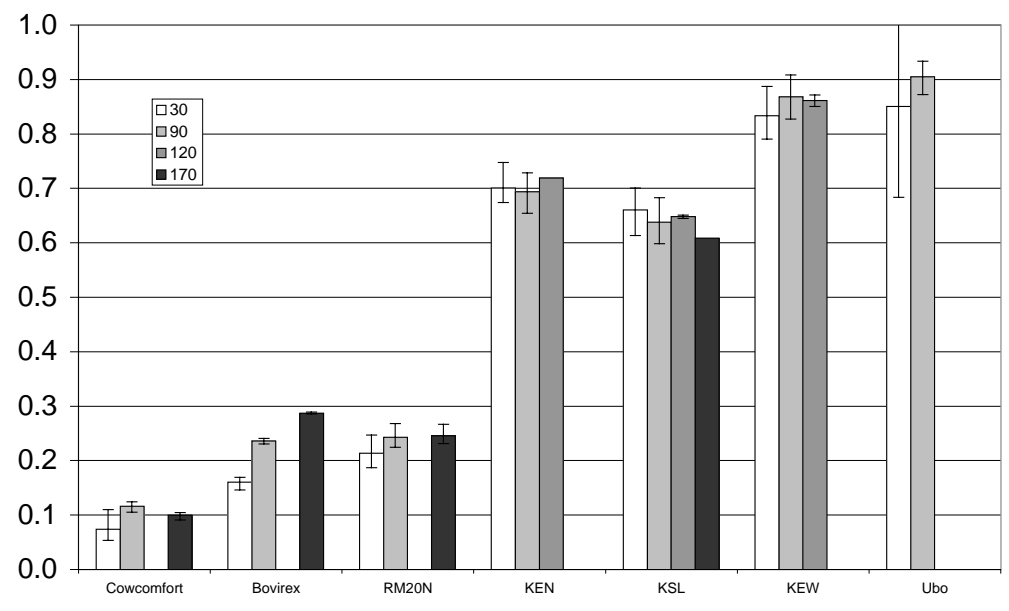


Vol. 14 (2005): 134-142.

Table 2. Physical properties of bedding materials. The friction coefficient was calculated from Eq. (4), the Young's modulus from Eq. (3) using the artificial hoof measurements (Fig. 5). The heat flux values at the two representative time instances were taken from the test series of Figure 1. The penetration of the (model) kneecap when the load is $400 \mathrm{~kg}$ are taken from the test series of Figure 4.

\begin{tabular}{|c|c|c|c|c|c|c|}
\hline & \multicolumn{2}{|c|}{ Friction coefficient } & \multirow{2}{*}{$\begin{array}{l}\text { Young's } \\
\text { modulus } \\
(\mathrm{MPa})\end{array}$} & \multicolumn{2}{|c|}{ Heat flux } & \multirow{2}{*}{$\begin{array}{c}\text { Deformation } \\
\text { at } 400 \mathrm{~kg} \\
(\mathrm{~mm})\end{array}$} \\
\hline & dry & wet & & $\begin{array}{l}10 \mathrm{~min} . \\
\left(\mathrm{W} \mathrm{m}^{-2}\right)\end{array}$ & $\begin{array}{l}60 \mathrm{~min} . \\
\left(\mathrm{W} \mathrm{m}^{-2}\right)\end{array}$ & \\
\hline KEN & 0.70 & 0.54 & 5.4 & 430 & 150 & 10 \\
\hline KSL & 0.64 & 0.58 & 4.6 & 400 & 120 & 14 \\
\hline RM20N & 0.23 & 0.29 & 5.5 & 420 & 140 & 10 \\
\hline Ubo & 0.88 & 0.92 & 10.8 & 460 & 200 & 7 \\
\hline Bovirex & 0.23 & 0.23 & 6.3 & 140 & 80 & 27 \\
\hline Cowcomfort & 0.10 & 0.07 & 6.7 & 120 & 50 & 16 \\
\hline KEW & 0.85 & 0.68 & 1.5 & 370 & 40 & 23 \\
\hline
\end{tabular}

Weight $(\mathrm{kg})$

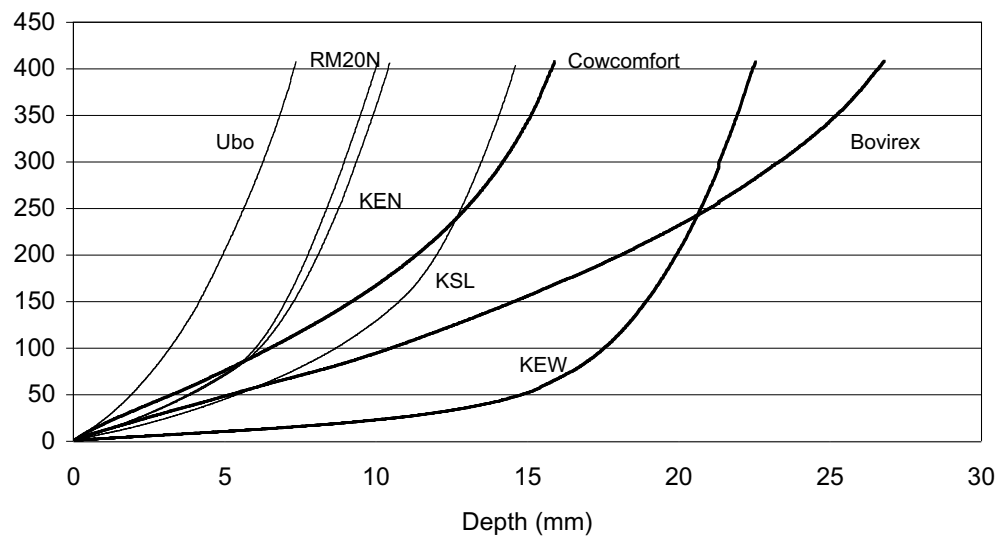

Stress (MPa)

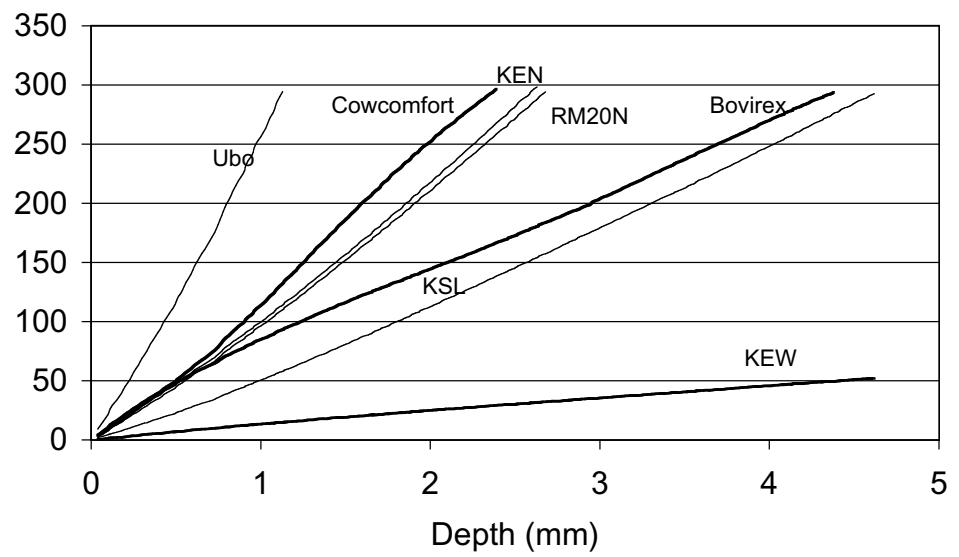

Fig. 4. Deformation as a function of the pressing force using the steel ball.
Fig. 5. Deformation as a function of the stress using the artificial hoof. 
method (FEM) -calculations with ABAQUS-program (ABAQUS, Inc.) were also performed. They were in agreement with the experimental results.

\section{Discussion and conclusions}

As animal houses and indoor conditions differ in many respects, it is useful to study the physical properties of various bedding materials in order to see which of the materials is optimal for the heat balance of cows in winter or summer or in a freestall or tied-stall and which of the materials is most cost effective and safe.

The physical properties of bedding materials vary considerably in all the respects studied (Table 2 ). The heat flux to the bedding was shown to be large enough to affect the cow's heat balance. The total heat production of a milking cow is about 1 $\mathrm{kW}$. Heat loss to the floor during the first minutes may well be of the same magnitude taking into account the area of the cow against the floor and the low temperature of the bedding in winter (Fig. 1). The heat flux after 60 min gives information about the comfort of the bedding material over longer lying times. A low value indicates a 'warm' material and a high value indicates a 'cold' material. In cold conditions a 'warm' material is preferable, but in warm conditions it can be too hot. Heat flux after 10 minutes tells if the material feels warm or cold just after lying down and it can have an effect on the attractiveness of the material. Initially comfortable bedding may become uncomfortable over a longer period, and similarly an uncomfortable bed may become comfortable.

It should be noted that heat balance calculations in the literature are based on steady state conditions, i.e. the situation when the heat flow has stabilized, which takes about an hour. The relevance of this is questionable, since the typical lying time of milking cows is only one hour. The Eqs. (1) and (2) facilitate more sophisticated calculations where the time dependence of the phenomena can also be included. Equally recommendations for the suitable temperature range in the stall are at most based on static, non-dynamic, calculations. It is evident that the recommendable temperature range depends on the heating power of the animal, i.e. whether milking cows or beef cattle are being considered and on the bedding material and the housing conditions. The results give good basic information for choosing suitable bedding material in varying conditions after the heat balance calculation is performed for the chosen situation. It is evident that in winter and in summer or on the other hand for milking and for non-milking cows different kinds of thermal properties of lying materials are the best for cow's well-being.

The friction coefficients also vary. There are clearly both slippery and non-slippery materials. If we compare the results to the recommended friction of 0.3-0.5 (Wander 1970, Beer 1976, Bähr and Türpitz 1976, Nilsson 1978), we found that most of the tested materials are not in this range. However, the friction values were not absolute, as the material and the shape of the artificial hoof were not identical to natural hooves, the results are only indicative and they should be used solely for comparison purposes. Friction values will also change during usage since urine, manure and wear influence friction. In order to better compare friction characteristics beds should also be compared with each other after some usage time. Furthermore, the connection between slipping and friction coefficient is not straightforward. If the floor is slippery, the cow walks more carefully and will not slip.

There were also differences of almost an order of magnitude in the softness (Young's modulus) of the mats. Some of the mats were very soft and some were hard. Demands for softness vary according to the type of building and a cow with an injured leg needs softer bedding. The material has to be comfortable enough for lying and moving on the bed. Nilsson (1988) has given recommendations for the softness values which are based on the floor preference of cows. According to Nilsson (1988), in the iron ball test a suitable sinkage is $10-25 \mathrm{~mm}$, when the load is $200 \mathrm{~kg}$. All the materials except Ubo are approximately within this range (Fig. 4). 
Vol. 14 (2005): 134-142.

The properties of mats and beds varied considerably and the various properties did not correlate with each other. More information is needed concerning these values to animal welfare and health in order to be able to make recommendations of different physical material characteristics in different climate and housing conditions.

Bedding materials have to fulfill the demands of both the animals and farm workers or farmers. For the animal welfare aspects are the most important and from the human perspective hygiene, durability and economy are significant. When different stall types and weather conditions are included, the choice of bedding material is not straightforward, but the materials have to be chosen case by case. The results of this study should help in the decision-making process.

\section{References}

Bähr, H. \& Turpitz, L. 1976. Die Trittsicherheit von Stallfussböden und der Einflussfaktor Reibwiderstand. Agrartechnik 5: 241-243.

Beer, G. 1976. Einige neue Prüfundsmethoden für die Tierstallböden. Report from the working session of the 2nd technical session of comission international du Genie Rural, Budapest, 21-24 September. p. 473-478.

Britten, A.M. 1994. Dairy free stall bedding systems and udder health. In: Bucklin, R. (ed.). Dairy systems for the 21st century. Proceedings of the Third International Dairy Housing Conference, 2-5 February 1994, Orlando, Florida: ASAE. p. 165-172.

Cermak, J. 1988. Cow comfort and lameness - design of cubicles. Bovine Practitioner 23: 79-83.

Dumelov, J. 1995. Testing cubicle mats for dairy cows. Agricultural Engineering 50: 17-21.

Duncan, I.J.H. 1992. Measuring preferences and the strength of preferences. Poultry Science 71: 658-663.

Faull, W.B., Hughes, J.W, Clarkson, M.J., Downham, D.Y., Manson, F.J., Merritt, J.B., Murray, R.D., Russell, W.B., Sutherst, J.E. \& Ward, W.R. 1996. Epidemiology of lameness in dairy cattle: the influence of cubicles and indoor and outdoor walking surfaces. Veterinary Recearch 134: 490-494.

Haley, D.B., Rushen, J. \& de Passillé, A.M. 2000. Behavioural indicators of cow comfort: activity and resting behaviour in two types of stalls. Canadian Journal of Animal Science 80: 257-263.

Herlin, A. 1997. Comparison of lying area surfaces for dairy cows by preference, hygiene and lying down behaviour. Swedish Journal of Agricultural Research 27: 189196.
Hogan, J.S., Smith, K.L., Hoblet, K.H., Todhunter, D.A., Schoenenberger, P.S., Hueston, W.D., Pritchard, D.E., Bowman, G.L., Heider, L.E., Brockett, B.L. \& Conrad, H.R. 1989. Bacterial counts in bedding materials used in nine commercial dairies. Journal of Dairy Science 72: $250-258$.

Incropeda, F. P. \& de Witt, D.P. 1990. Fundamentals of heat and mass transfer. John Wiley \& Sons. $260 \mathrm{p}$.

Irish, W.W. \& Martin, R.O. 1983. Design considerations for free stalls. Proceedings of the Second National Dairy Housing Conference, March 14-16, Madison, Wisconsin: ASAE. p. 108-121.

Leonard, F.C., O'Connell, J.O. \& O'Farrell, K.O. 1994. Effect of different housing conditions on behaviour and foot lesions in Friesian heifers. Veterinary Research 134: 490-494.

Manninen, E., de Passillé, A.M., Rushen, J. \& Saloniemi, H. 2002. Preferences of dairy cows kept in unheated buildings for different kind of cubicle flooring. Applied Animal Behaviour Science 75: 281-292.

Müller, C., Ladewig, J., Thielscher, H.H. \& Smidt, D. 1989. Behaviour and heart rate of heifers housed in tether stanchions without straw. Physiology \& Behaviour 46: 751-754.

Müller, C.J.C. \& Botha, J.A. 1997. Cow behaviour in relation to different freestall surfaces during winter in a temperate climate. In: Bottcher, R.W. \& Hoff, S.J. (eds.). Proceedings of the Fifth International Symposium, 29-31 May, 1997, Bloomington, Minnesota: ASAE. p. 10691076.

Munksgaard, L. \& Løvendahl, P. 1993. Effects of social and physical stressors on growth hormone levels in dairy cows. Canadian Journal of Animal Science 73: 847853.

Munksgaard, L. \& Simonsen, H.B. 1995. Behavioural and pituitary-adrenal axis responses of tethered cows or cows kept in pens with slatted floors. Acta Agriculturae Scandinavica, Section A: Animal Science 45: 132-138.

Natzke, R.P., Bray, D.R. \& Everett, R.W. 1982. Cow preference for free stall surface material. Journal of Dairy Science 65: 146-153.

Nilsson, C. 1978. Floors in animal buildings - Technical demands. Swedish University of Agricultural Sciences, Department of Farm Buildings, Report 3. 69 p.

Nilsson, C. 1988. Floors in animal houses. Technical design with respect to the biological needs of animals in reference to the thermal friction and abrasive characteristics and the softness of flooring material. Swedish University of Agricultural Sciences, Department of Farm Buildings Report 61.39 p.

Nilsson, C. 1992. Walking and lying surfaces in livestock houses. In: Piggins, C. \& Piggins, D. (eds.). Farm animals and the environment. CAB International, Wallingford. p. 94-99.

O'Connell, J.M., Giller P.S. \& Meaney, W.J. 1993. Weanling training and cubicle usage as heifers. Applied Animal Behaviour Science 37: 185-195.

Singh, S.S., Ward, W.R., Lautenbach, J.W., Hughes, J.W. \& Murray, R.D. 1993. Behaviour of first lactation and adult dairy cows while housed and at pasture and its relationship with sole lesions. Veterinary Research 133: 469-474. 
Sonck, B., Daelemans, J. \& Langenakens, J. 1999. Preference for free stall surface material for dairy cows. Presented at the ASAE-CSAE-SCGR Annual International Meeting, Toronto, Ontario, Canada, 18-21 July 1999: ASAE. Paper No. 994011.10 p.

Spillman, C.K. \& Hinkle, C.N. 1971. Conduction heat transfer from swine to controlled temperature floors. Transactions of the ASAE 1971: 301-303.

Tierney, G. \& Thomson, R.D. 2001. The role of finite-element analysis in predicting the injury-reduction potential of dairy cow cubicle synthetic beds. Journal of Agricultural Engineering Research 80, 4: 373-379.
Wander, J.F. 1970. Einige Ansprüche der Rinder an der Stellfusboden. Comission International du Genie Rural Conference, Gent. Section 2, Vol. 1, 13.1-13.9.

Weary, D.M. \& Taszkun, I. 2000. Hock lesions and free-stall design. Journal of Dairy Science 83: 697-702.

Webster, J. 1993. Understanding the dairy cow. Blackwell Scientific Publications. $95 \mathrm{p}$.

Wechsler, B., Schaub, J., Friedli, K. \& Hauser, R. 2000. Behaviour and leg injuries in dairy cows kept in cubicle systems with straw bedding or soft lying mats. Applied Animal Behaviour Science 69: 189-197.

\title{
SELOSTUS
}

\section{Synteettisten makuualustamateriaalien fysikaaliset ominaisuudet}

\author{
Jukka Ruunaniemi, Mikko Hautala ja Jukka Ahokas \\ Helsingin yliopisto
}

Tuotantoeläinten hyvinvointiin on viime vuosina alettu kiinnittää enemmän huomiota kuin aikaisemmin. Lypsylehmien parsien mukavuutta on pyritty lisäämään parsimatoilla ja viime aikoina parsipatjoilla ja -pedeillä. Näiden ns. synteettisistä materiaaleista valmistettujen alustojen yleistymistä on lisäksi edesauttanut niiden mahdollistama parsien kuivittamisen vähentäminen eli säästö työmäärässä. Parren mukavuutta lehmän kannalta on selvitetty eri tutkimuksissa, ja tärkeimmiksi parren fysikaalisiksi ominaisuuksiksi lehmän kannalta ovat nousseet kitka, pehmeys ja lämpövirta.

Tämän tutkimuksen tavoitteena oli mitata Suomessa myytävien makuualustojen lehmien hyvinvoinnin kannalta tärkeimmät fysikaaliset ominaisuudet. Tutkimusmenetelminä käytössä olivat lepokitkakertoimen määrittämiseen vetokoe, pehmeyden määrittämiseen puristuskoe ja lämpöominaisuuksien määrittämiseen lehmämalliin perustuva lämpövirtakoe.

Kitkan suositusarvona on 0,3-0,5. Jos kitka on suurempi, seurauksena on hiertymiä, jos se on alhaisempi, seurauksena on liukastumisia. Mattojen (UBO, RM 20N, KEN, KSL, Cow Comfort, Bovirex ja KEW) kitkat vaihtelivat melkoisesti eivätkä kaikki matot olleet suositusrajoissa. Käytössä kitka-arvot muuttuvat lannan, virtsan ja kulumisen vaikuttaessa, ja vertailtavuuden vuoksi olisi hyvä tehdä kitkamittauksia myös käytössä olleista matoista.

Mattojen pehmeydet vaihtelivat pehmeistä koviin. Pehmeysvaatimukset vaihtelevat esim. lehmien sorkkien kunnon mukaan. Sorkkaongelmainen lehmä valitsee pehmeämmän alustan kuin tervesorkkainen. Kova alusta aiheuttaa hiertymiä ja pehmeällä alustalla seisominen on epävakaata. Pehmeyden suosituksena on 10-25 mm painuma 200 kg:n kuormalla. Lähes kaikki matot ovat tällä alueella.

Mattojen lämmönjohtavuus ei ole yksiselitteinen, koska olosuhteiden vaihdellessa myös lämpövirran mattoon pitäisi muuttua. Kylmässä pieni lämpövirta on hyväksi ja kuumassa päinvastoin. Materiaalin houkuttelevuuteen vaikuttaa myös sen lämpövirta lehmän asettuessa makuulle. Materiaali voi olla alussa mukava, mutta pidemmän ajan jälkeen liian kuuma tai päinvastoin.

Tuloksia tulkittaessa on kuitenkin syytä kiinnittää huomiota eri kriteereiden keskinäiseen järjestykseen mattovalintaa tehtäessä. Esimerkiksi Suomen olosuhteissa käytössä on yleensä lämmin tuotantorakennus ja tällöin alustan eristävyydellä ei ole niin suurta merkitystä. Näissä olosuhteissa kriteerien järjestys mattovalintaan vaikuttamisessa voisikin olla seuraava: kitka, pehmeys, lämpövirta. 